\title{
Analysing the conceptual framework of religious freedom and interreligious relationship in Islam
}

\author{
Mohd Roslan Mohd Nor \\ Department of Islamic History and Civilization, Academy of Islamic Studies, \\ University of Malaya, Malaysia \\ E-mail:m_roslan@um.edu.my
}

\section{Issa Khan}

Department of Shariah and Management, Academy of Islamic Studies, University of Malaya, Malaysia

E-mail: shahaalam83@gmail.com

\section{Mohammad Elius}

Department of Islamic History and Civilization, Academy of Islamic Studies, University of Malaya, Malaysia, and Department of World Religions and Culture, University of Dhaka, Bangladesh

E-mail:elius_re@yahoo.com

DOI: 10.18326/ijims.v8i2. 309-334

\begin{abstract}
This study evaluates the concept of religious freedom and interreligious relationships in Islam. The research engages in textual analysis and historical interpretation of the Qur'an and Sunnah (the Prophetic tradition) regarding the freedom of religious beliefs and practices as well as Muslim relationships with people of other religions. The study shows that Islam plays a unique role
\end{abstract}


in providing every individual with the complete freedom to possess and practice any religion, culture or ideology. It also shows that as a universal religion, Islam advocates a harmonious relationship among the people of different religions, cultures and civilisations for the peaceful coexistence and harmonious development of all human beings. The study concludes that Islam as a complete way of life preserves the beliefs and practices of every individual and maintains a peaceful relationship between the followers of one religion and another. It constitutes a viable model for resolving religious hatred and promoting peace and justice among people of diverse ethnic, religious and cultural backgrounds.

Keywords: Religious freedom; Interreligious relationship; Islam; Qur'an; Sunnah

\section{Introduction}

Religion is sometimes conceptualised as individual dealings with a supernatural phenomenon involving beliefs, rituals and certain moral principles. It is considered a spiritual matter concerned with the personal or private affairs of human life. ${ }^{1}$ Muslim scholars define religion as a law given by Allah to mankind through His selected Prophets to attain goodness in this world and the world hereafter. ${ }^{2}$ The issue of religious freedom and interreligious relationships has become an interesting area of study among researchers over the last few decades. It has a logical connection between fundamental human rights and individual freedom of choice. ${ }^{3}$

We are living in an age of globalisation in communities comprising

\footnotetext{
${ }^{1}$ Ahmad, F. Yousif, "Western Concept of Religious Freedom: a Critique", in Religious freedom, Minorities and Islam: An Inquiry into the Malaysian Experience, Selangor Darul Ehsan: Thinkers Library SDN BHD, 1998, 10.

${ }^{2}$ Fatma Bayram, What is Religion? Accessed December 5, 2017. http://www.lastprophet. info/what-is-religion.

${ }^{3}$ Siti Zubaidah Ismail and Muhamad Zahiri Awang Mat, "Faith and Freedom: The Qur'anic Notion of Freedom of Religion vs. the Act of Changing Religion and Thoughts on the Implications for Malaysia”, Religions Volume 7, Number 7 (2016), 1-18.
} 
people of diverse ethnic, religious and cultural backgrounds. ${ }^{4}$ Every day we interact with the followers of different religions as neighbours, colleagues, classmates, friends, and so on. Thus, we experience different aspects of different religions as part of our daily life. ${ }^{5}$ As a universal religion, Islam teaches love and sympathy for all humanity. It is a complete way of life which prohibits intervening in the beliefs and practices of other religions and seeksto preserve the customs, honour, and property of every individual irrespective of his or her religion. ${ }^{6}$

Muslims have played a major role in promoting religious freedom and maintaining harmonious interreligious relationships since the beginning of Islam. ${ }^{7}$ The Qur'an provides multiple examples of religious freedom and positive interreligious relationships. ${ }^{8}$ The Prophet Muhammad (pbuh) was a model for positive engagement with the people of different faiths and traditionseven before he achieved Prophethood. ${ }^{9}$ In his youth, Muhammad (pbuh) witnessed a perpetual feud among the Arab tribes known as 'Harb ul-Fijar', which caused the death of many people. ${ }^{10} \mathrm{He}$ felt distressed watching this inhuman activity, and with the help of the tribes, Muhammad (pbuh) established a peace association

${ }^{4}$ Hilal Wani, Raihanah Abdullah, and Lee Wei Chang, "An Islamic Perspective in Managing Religious Diversity”, Religions Volume 6, Number 2 (2015), 642-656. DOI: 10.3390/rel6020642.

${ }^{5}$ V. F. Vineeth C.M. I., "Interreligious Dialogue: Past and Present a Critical Appraisal", Journal of Dharma: Dharmaram Journal of Religions and Philosophies Volume 19, (1994), 36-58.

${ }^{6}$ Osman Zümrüt, "Some Reflections on Islamic View of Other Divine Religions within the Context of Inter-religious Dialogue", Journal of Religious Culture, Issue 91 (2007), 1-7. Available online: http://publikationen.ub.uni-frankfurt.de/opus4/frontdoor/index/ index/docId/493. Accessed on 20 June 2018.

${ }^{7}$ Khairulnizam Mat Karim, Suzy Aziziyana Saili, "Inter-faith dialogue: The Qur'anic and Prophetic Perspective", Journal of Usuluddin Volume 29, (2009), 65-94.

${ }^{8}$ Al-Qur'an, 2: 256; 109: 6; 49:13; 5: 48; 16: 125

${ }^{9}$ Abd al-Malik Ibn Hisham, Sirah al- Nababiyah, Vol. 1, Egypt: Sharika Maktaba, 1955, 197.

${ }^{10}$ Hafiz Ghulam Sarwar, "Darkness and Dawn"in Life of Muhammad, London: The Writers House, 2010, 29-30. 
IJIMS: Indonesian Journal of Islam and Muslim Societies, Volume 8, Number 2, December 2018: 309-334

known as 'Hilful Fudul'. The Prophet (pbuh) played a significant role in this great initiative. ${ }^{11}$ People of Makka used to call him al-Amin, 'the trustworthy', ${ }^{12}$ and as-Sadiq, 'the truthful'. ${ }^{13}$ The history of Islam offers numerous examples of the tolerant and liberal attitudes of Muslim rulers toward the followers of other religions. ${ }^{14}$ Today, Islam is often misunderstood because ofthedestructive activities of those with little or incorrect knowledge of Islam, who the public take as representatives of Muslims and Islamic teachings. ${ }^{15}$

Research has already been conductedon religious freedom and interreligious relationshipsin Islam. ${ }^{16}$ Further research on this issue is necessary for mitigating ambiguity and confusion. This study analyses the concept of religious freedom and interreligious relationships from the Qur'anicperspectiveand Prophet's dealing with the people of other religions in order toabate conflictsand promote peace and understanding.

${ }^{11}$ Abdul Hamid Siddiqui, The Life of Muhammad, Kuala Lumpur: Islamic Book Trust, 1999, 51.

${ }^{12}$ John L. Esposito, "Mohammad and the Quran: Messenger and Message", in Islam: The straight Path, London: Oxford University Press, 1988, 8.

${ }^{13}$ Ahmet Kurucan and Mustafa Kasim Erol,Dialogue in Islam: Quran- Sunnah- History, London: Dialogue Society, 2012, 18.

${ }^{14}$ For instance, Umar al-Khattab has granted safety to the people of Aelia, Muslims and non-Muslims alike, with the condition that they pay the jizya. Those who does not agree and would like to leave, they will be escorted until they reach the safe place for their living. This is stated in the document called al-Uhda al-Umariyyah. Please see Abd al-Fattah El-Awaisi, Umar's Assurance of Safety to the People of Aelia:A Critical Analytical Study of the Historical Sources. Journal of Islamic Jerusalem Studies, Volume 3, Number 2 (2011), 1-50.

${ }^{15}$ Syed Anwar Husain, "Islamic perspective of interfaith harmony and dialogue", The $2^{\text {nd }}$ International Conference on Interreligious and Intercultural Dialogue, Dhaka: University of Dhaka, Nov. 27-29, 2010, 34-42.

${ }^{16}$ Ahmad, F. Yousif, "Western Concept"; see also Ali Muhammad Bhat, "Freedom of expression from Islamic perspective", Journal of Media and Communication Studies, Volume 6, Number 5 (2014), 69-77; Siti Zubaidah Ismail and Muhamad Zahiri Awang Mat, 2016; Muhammad Hashim Kamali, "Diversity and Pluralism: A Quranic Perspective", Islam and Civilizational Renewal, Volume 1, Number 1 (2009), 27-54. 


\section{The Quranic framework of religious freedom}

The word 'freedom' is interpreted as a state of being free, self-reliant and frank in the use of ideas and opinion. It is the power to think, speak and act without any kind of restrains. ${ }^{17}$ Religious freedom is a state where individuals can associate freely with any religious beliefs having no fear of discrimination or persecution. ${ }^{18}$

Islam guarantees liberty to individuals and enables them to search for truth freely. ${ }^{19}$ Islamic teachings supporta person's freedom to choose their religion and way of life.Many verses in the Qur'an describe the freedom of religious practices. The Qur'anic injunction of religious freedom came during the Prophet's (pbuh) stay in Makkah.A group of idolaters came to the Prophet and proposed that if he (the Prophet) worshipped their gods and goddesses this year, then they will worship Allah in the following year. The chapter of the Qur'an named al-Kafirunwas revealed in response to their proposal. The Qur'an says: "I do not worship what you worship, noryou worship that which I worship. And I will not worship that which you worship, nor you will you that which I worship. For you your religion, and for me mine". ${ }^{20}$

These verses clarifies that the Prophet can neither force anybody to followIslam nor be forced to follow his or her religion. Everybody is free to believe and practice his or her religion.In his Jami al-Qur'an, al-Qurtubi ${ }^{21}$ asserts that we cannot impose Islam on anybody. Everybody must enjoy

\footnotetext{
${ }^{17}$ Ahmad, F. Yousif, "Western Concept..., 10.

${ }_{18}$ Anshuman A. Mondal, "Articles of Faith: Freedom of Expression and Religious Freedom in Contemporary Multiculture", Islam and Christian-Muslim Relations, Volume 27, Number 1 (2016), 3-24. DOI: 10.1080/09596410.2015.1114240.

${ }^{19}$ Mohammadi Ali, "The Culture of Politics of Human Rights in the Context of Islam", in Islam Encountering Globalization, ed, USA: Routledge Curzon, 2002, 117.

${ }^{20} \mathrm{Al}$-Qur'an, 109: 2-6.

${ }^{21}$ Abu Abdullah Muhammad al-Qurtubi, Al-Jāmi' al-Ahkām al-Qur'àn, Vol. 4, Cairo: Dar al-Kutub al-Misriyyah, 1964, 281.
} 
freedom in choosing and practising his or her religion.The Quran prohibits compulsion in choosing religion. If anybody accepts truth, it will benefit him or her, and if anybody errs and is adamant to remain astray, it is also their choice and they must live with the consequences. The Quran says in this regard:

"And say, the truth is from your Lord, so let him believe who wills and let him disbelieve who wills".22

Other Quranic verses also clarify that Truth has come from Allah, and it is the individuals who can receive guidance from it for their benefit andcan reject or denyit at their detriment. Allah and His Prophet will not force them to believe. ${ }^{23}$ Hence, people have complete freedom regarding their choice of religion. The Quran clarifies:

"There shall be no compulsion in religion. The right way is, indeed, clear from the wrong." 24

The verse is reported to have been revealed in the fourth year after Hijrah when the Makkan disbelievers continuedtheir war against Muslims. Some companions sought the permission of the Prophet to compel the children who were following Judaism to embrace Islam. The Prophet (pbuh) did not allow this. This verse provides clear injunction so that no one can compel anybody to embrace Islam.

In an Islamic society, non-Muslims have the right to be judged by the standards of their religion. The Quran says: "And let those who follow the Gospel be judged by the revelation given by Allah to them". ${ }^{25}$ They have the right to make their house of worship, i.e. churches, temples and synagogues. They can carry out missionary activities for propagating

\footnotetext{
${ }^{22}$ Al-Qur'an, 18: 29.

${ }^{23}$ Al-Qur'an, 10: 108; 39: 41.

${ }^{24}$ Al-Qur'an, 2:256.

${ }^{25}$ Al-Qur'an, 5: 47.
} 
their religion and enjoy the freedom to bring up their children according to their faith. ${ }^{26}$ Muslim jurists agree that the Islamic state has the responsibility to provide religious freedom to its non-Muslim citizens so long as they do not threaten the integrity and security of the state and abuse the privileges. ${ }^{27}$

Imposing Islam to anybody against his or her will is against the teachings of Islam. Allah does not want nor accepts forceful conversions. Allah has reminded that if He wanted, He could have made all people believers as in the verse: "If Allah willed, all human beings would believe. So will you force them to believe?"28 Elsewhere, He states: "If Allah willed He would make you one community". ${ }^{29}$ It is understood from theabove verses that differences in religionare part of Allah's plan and design.Muslims mustaccept that it is not their responsibility to forcefully make othersMuslim. They must learnto live with other religions in love, sympathy, cooperation and mutual understanding. ${ }^{30}$

According to Islam, a person is born free from sin, subjugation or inherited inferiority. Although man is born free, he does not have absolute freedom in the sense that only Allah possesses the absolute freedom. Individuals have been giventhe freedom to develop their potential by which theycannot violate the rights of others. ${ }^{31}$ The Satanic approach to freedom is depriving othersof their rights while the angelic approach is

${ }^{26}$ Ahmad, F. Yousif, "Islamic Perspective of Religious Freedom", in Religious freedom, Minorities and Islam: An Inquiry into the Malaysian Experience, Selangor Darul Ehsan: Thinkers Library SDN BHD, 1998, 38.

${ }^{27}$ Ali Muhammad Bhat, 2014.

${ }^{28}$ Al-Qur'an, 10: 99.

${ }^{29}$ Al-Qur'an, 5: 48.

${ }^{30}$ Ahmet Kurucan and Mustafa Kasim Erol,Dialogue in Islam: Qur'an- Sunnah- History, London: Dialogue Society, 2012, 37.

${ }^{31}$ Mohsen Kadivar, "Apostasy, Blasphemy, \& Religious Freedom in Islam: A Critique Based on Demonstrative Jurisprudence", in Islam and Human Rights Series No. 2, 2014. Available online http://kadivar.com (accessed on January 2, 2018). 
peace-loving. For example, Pharaoh enslaved the Israelites misusing his right to freedom while Prophet Musa (Moses) stood against him in the name of the same freedom. ${ }^{32}$

Khurshid Ahmed as quoted by Yousif ${ }^{33}$ argued thatIslam is a religion not confined to personal or private affairs but is a guide for every aspect of human life including individual, social, political, economic, moral, cultural, legal, national and international.For Muslims, ritualistic practices are not enough for fulfilling religion. Having faith in the Oneness of Allah (Tawhid) is the cornerstone of Islam.Islam provides every individual with thefreedom to express so long it does not interfere with the nobility and freedom of others. There is no room for being offensive and spreading evil. Islam does not regardabusiveor ridiculous language part of freedom. ${ }^{34}$ In Denmark, the publication of cartoons thatcreated false and negative attitudestoward Prophet Muhammad (pbuh)and the issue of hijab of in France and Australia as well as burning the holy Quran in Indiais unfortunate and should not be considered a part of freedom or liberty. Such inflammatory acts are against the true spirit of religion which supports thefreedom of expressionwithin the boundaries of equity.

\section{Religious freedom practised by the Prophet}

The Prophet (pbuh) implemented the Quranic teachings in practice. He never imposed Islamic laws on non-Muslims in Madinah. ${ }^{35}$ Abu Hurairah

32 Abdul Hai Madani, "Freedom and Its Concept in Islam", 2nd International Conference on Humanities, Historical and Social Sciences IPEDR, Vol.17, (2011), IACSIT Press, Singapore, 16-20.

33 Ahmad, F. Yousif, "Western Concept..., 29.

${ }^{34}$ Taysir M Mandour, "Islam and Religious Freedom: Role of Interfaith Dialogue in Promoting Global Peace”, BYU L Rev. Volume 3, (2010), 885-893.

${ }^{35}$ Abdullah Al Masud and Mohammad Elius, "The Qur'anic View of Interreligious Dialogue and Harmony", International Journal of Recent Research in Social Sciences and Humanities Volume 3, (2016), 18-21. 
narrated that once a group of Jewish scholars came to the Prophet (pbuh) and declared that one of them committed adultery and they wanted him to judge the matter. The Prophet of Islam (pbuh) judged the issue according to Jewish scripture. ${ }^{36}$ The Prophet's rule in Madinah is a true example of religious freedom and interreligious harmony. He established an ideal community based on shared goals in Madinah. ${ }^{37} \mathrm{He}$ formeda charter toregulate the affairs of all citizens irrespective of their religion. ${ }^{38}$ The Charter was mediated by the Prophet (pbuh) between Muslims and the Jewish, polytheistic and ethnic groups of Madinah. Muhammad (pbuh) signed an agreement: "The Jews of Banu 'Awf are a community (ummah) along with the believers. To the Jews their religion (din) and to the Muslims their religion. For maintaining harmony and peaceful coexistencebetween the parties, there was a common legal, economic, military and political goal in this Charter ${ }^{39}$ which aimed to protect the lives and properties of its inhabitants in Madinah, fight against hostilities and injustice irrespective of religious or tribal affiliation and ensure religious freedom. Muslims and Jews lived side by side in harmony. ${ }^{40}$ It is said that the Charter of Madinah is the first written and modern constitution in history. The Charter was the foundation for a pluralistic and tolerant polity in Madinah.

\footnotetext{
${ }^{36}$ Muhammad Ibn Jarir al- Tabari, Jamiul Baiyan Fi Tawil al-Qur'an, Vol.10, Beirut: Muassalah al-Risalah, 2000, 303.

${ }^{37}$ Faatin Haque, "Countering Religious Militancy through Interfaith Cooperation: An Islamic Perspective”, World Universities Congress, Canakkale Onsekiz University, Turkey, (2010), 20-24.

${ }^{38}$ Ali Ihsan Yitik, "Islam and Pluralism: Does Qur'an Approve Pluralism"? Journal of Religious Culture, Number 68, (2004), 1-5. Available online:http://publikationen.ub.unifrankfurt.de/opus4/frontdoor/index/index/docId/468. Accessed 20 June 2018.

39 Ahmet Kurucan and Mustafa Kasim Erol, Dialogue in Islam..., 74.

${ }^{40}$ Maher Y. Abu- Munshar, "Islamic Sources and the Treatment of non-Muslims", in Islamic Jerusalem and Its Christians: A History of Tolerance and Tensions, New York: Tauris Academic Studies, 2007, 41.
} 
Muhammad (pbuh) made many other agreements with the inhabitants of Madinah. His treaty with the Christian representatives of Najran is anotherexample of religious freedom in Islam. The Prophet of Islam (pbuh) granted the prayer of the Christian deputation in the mosque and entered with them into a formal peace treaty. The treaty is as follows:

"No clergy's or monk's post shall be changed,nobody shall be denied travel, their places of worship shall not be destroyed or turned into Islamic masjids or added to Muslims' buildings. ... If they (Christians) need help from Muslims with repairing their churches, monasteries or any other religious or worldly business, Muslims shall help them without placing them under any obligation; help and support for their religious needs shall be provided out of abiding by the promise of God's Messenger, as a donation and as God's grace". ${ }^{41}$

In many cases, Prophet Muhammad (pbuh) would discuss the problems the Jews were encountering very often. He guaranteed teaching and learning of religious education for all. He used to visit Baitul Midras, the religious schools of the Jews. Abu Bakar, the first caliph of Islam, followed this practice to maintain the smooth functioning of religious education. ${ }^{42}$

\section{Interreligious relationship based on the Quran}

Human beings are the unique creation of Allah and are tasked with learning to live in harmony with others. ${ }^{43}$ The Qur'an teaches that all human beings, regardless of their religious and cultural affiliation, came from the same origin of Adam and Hawwa (Eve). Allah says: "O mankind! Fear your Lord Who created you from one soul and created from it its mate and dispersed from both of them many men and women" 44 and

\footnotetext{
${ }^{41}$ Ahmet Kurucan and Mustafa Kasim Erol, Dialogue in Islam..., 80.

${ }^{42}$ Abu Abdullah Muhammad al-Qurtubi, al-Jämi'..., 50.

${ }^{43}$ Mohd Roslan Mohd Nor, "Religious Tolerance in Malaysia: An Overview", Middle-
} East Journal of Scientific Research, Volume 9, Number 1 (2011), 23-27.

${ }^{44}$ Al-Qur'an, 4: 1. 
"O mankind, indeed We have created you from a male and a female and made you nations and tribes that you may know one another". ${ }^{45}$ A comprehensive idea of unity is expressed here by emphasising the shared origin of humankind. The verses also state that differences in race and nationality are to understand one another. Khambali asserts that the Qur'anic direction of knowing one another is a model for an interreligious relationship. ${ }^{46}$ To achieve this, it is necessary to maintain harmonious relations between people through mutual understanding and the absence of suspicion and hatred. The unity of mankind's origin is the basis of equality in Islam irrespective of religious and cultural identity.

In his farewell address, the Prophet Muhammad (pbuh) said: O' People! You are created by one Creator, and you are also the descendants of the same father. So, there is no superiority of the Arabs over those of non-Arabs. The white is not superior to the black and vice versa, except on the degree of righteousness. ${ }^{47}$ Nobody can claim his or her superiority over others. Everybody should respect others and maintain a mutual understanding between them. There should be no suspicion and hatred between one another.

According to Qur'anic teachings, there has not been one law for all humanity. Allah sent a Prophet to every community, and there were different Prophets for different communities. ${ }^{48}$ Islam considers itself the continuation of all previously revealed scriptures and teachings. For example, Prophet Nuh (pbuh) was called the submitter (Muslim). ${ }^{49}$

${ }^{45}$ Al-Qur'an, 49: 13.

${ }^{46}$ Khadijah Mohd Khambali, "Dialogue of Life: An Experience in Leeds Community", Journal of Usuluddin, Volume 41 (2015), 147-167.

${ }^{47}$ Abu Abdur Rahman Muhammad Nasir Uddin Albani, Silsilatu al-Ahadith al-Sahihah, Vol. 6, Riyad: Maktabat al-Maaref, 1996, 449.

${ }^{48}$ Al-Qur'an, 5: 48; 22: 67; 2: 285.

${ }^{49}$ Al-Qur'an, 10: 72. 
IJIMS: Indonesian Journal of Islam and Muslim Societies, Volume 8, Number 2, December 2018: 309-334

Prophet Ibrahim (pbuh) (Abraham) was also called a Muslim in the Quran. ${ }^{50}$ Thus, Islam accepted all previous Prophets as the Prophets of Islam.Jews and Christians are referred to with great honour as the people of the Book (Ahl al-Kitab). Prophet Muhammad (pbuh) came from the same genealogical line as the descendant of Ibrahim (Abraham) through his son Ismael. ${ }^{51}$

The Quran asks Muslims to behave with wisdom and beautiful words when dealing with the people of other religions. ${ }^{52}$ Wisdom, beautiful words and gracious conduct are vital for forging friendships or harmonious relationships with others. Allah wants all human beings to be involved sympathetically and respectfully with one another irrespective of their beliefs. ${ }^{53}$ The Quran sets kindness as the standard for interacting with others who have not shown open enmity towards Muslims. ${ }^{54}$ The Qur'an also reminds of the common ground among the religions and asks Muslims to establish peaceful and cooperative relationships based on those common teachings. The Qur'an says: "Say (O Muhammad): $O$ people of the Scripture! Come to a common word between us and you, that we worship none but Allah, and that we associate no partners with Him, and that none of us shall take others as lords besides Allah" ${ }^{55}$ The Prophet Muhammad (pbuh) emphasised the common beliefs when he wrote letters to non-Muslim leaders. In his lettersto Negus, King of Abyssinia and Heraclius, King of Byzantium, the Prophet mentioned the same verse of the Qur'an. ${ }^{56}$

\footnotetext{
${ }^{50}$ Al-Qur'an, 3: 67.

${ }^{51}$ Ahmed Zewail, "Dialogue of Civilizations: Making History through a New World Vision”. In Jean Staune (ed.), SCIENCE Ëthe Search for Meaning: Perspective from International Scientists, London: Templeton Foundation Press, 2006, 94.

${ }^{52}$ Al-Qur'an, 16: 125.

${ }^{53}$ Ahmet Kurucan and Mustafa Kasim Erol, Dialogue in Islam..., 36.

${ }^{54} \mathrm{Al}$-Qur'an, 60: 8.

55 Al-Qur'an, 3:64.

${ }^{56}$ Maher Y. Abu-Munshar, "Islamic Sources..., 44-45.
} 
The Qur'an also forbids insulting the people of other religions. ${ }^{57}$ Itcategorically prohibits ridiculing other communities and referring to them inoffensive terms. ${ }^{58}$ Polytheism or idol worship is contrary to Tawhid. The Quran strictly prohibits idol worship, and those who belong to this group are called 'Mushrikin'. But the Quran did not advocate assaulting and persecuting the idol worshippers or plundering their properties. They are given the same right to be protected in an Islamic state. Muslims are commanded not only to ensure the protection of the idolaters when they come in contact with Muslims but also to ensure their safe journey home. ${ }^{59}$

It is sometimes asserted that the Quran forbids friendships with the followers of other religions. ${ }^{60}$ To clarify, the Qur'an prohibits formingfriendships with those who are openly at war with Muslims. ${ }^{61}$ Being in a state of war or open enmity is an exceptional case where there is active aggressionby the other party and diplomacy has failed. The Quran states: "Allah does not forbid you from those who do not fight you because of religion, and do drive you out from your homes, that you be righteous to them and deal justly with them. Surely, Allah loves those who do justly. Allah only forbids you as regards those who fight you because of religion, and drive you out from your homes and help (others) in your expulsion, that you make allies of them; and whoever makes allies of them are the wrongdoers". ${ }^{62}$ In bothverses, Allah only forbids Muslims to make allies of those who fight Muslims, expel them from their houses and conspire against them. On the other hand, for those who do not fight against Muslims, and do not expel them from

\footnotetext{
${ }^{57}$ Al-Qur'an, 6: 108.

${ }^{58}$ Al-Qur'an, 49: 11.

${ }^{59}$ Al-Qur'an, 9: 6.

${ }^{60} \mathrm{Al}$-Qur'an, 3: 28: 5: 51; 2: 120.

${ }^{61}$ Ahmet Kurucan and Mustafa Kasim Erol, Dialogue in Islam..., 40.

${ }^{62}$ Al-Qur'an, 60: 8-9.
} 
their houses, Muslims are obligated todeal with them with justice and righteousness. Abu Munshar explains that Muslims should interact with non-Muslims based on the principles of justice. They must maintain kindness and good relationships with non-Muslims in so long the latter does notseek the destruction of Islam and Muslims. ${ }^{63}$

Some critics argue that several Quranic verses make harsh remarks against non-Muslims. ${ }^{64}$ These verses should be understood in the context of their revelation. Verse 2: 191 refers to the polytheists of Makkah who tortured and killed the weaker Muslims and initiated hostilities and war. Verse 4: 89 refers to the hypocrites of both Makkah and Madinah who committed high treason against Muslims. ${ }^{65}$ Muslim scholars suggest that verses should not be appliedwith a thorough search of other verses or traditions which justify its interpretation. ${ }^{66}$ Nobody can justify a particular verse of the Quran or a Prophetic tradition separately if there are other verses or Hadith which offer a different or opposite meaning. To understand a particular verse of the Quran or a Hadith, it is necessary to have a holistic approach that considers all other Quranic verses and hadiths of the Prophet.

\section{Prophet Muhammad's (pbuh) treatment of the people of other religions}

Prophet Muhammad (pbuh) used to visitthe sick without considering his or her religious affiliation. He visited both Muslims and nonMuslims alike. ${ }^{67}$ The life of Muhammad (pbuh) encompasses numerous

\footnotetext{
${ }^{63}$ Maher Y. Abu- Munshar, "Islamic Sources..., 16.

${ }^{64}$ Al-Qur'an, 2: 191; 4: 89.

${ }^{65}$ Ahmet Kurucan and Mustafa Kasim Erol, Dialogue in Islam..., 44-45.

${ }^{66}$ Muhammad Haniff Hasan, "Interpreting Islam and Plural Society", Islam and Civilizational Renewal. Volume 1, Number 1 (2009), 99- 121.

${ }^{67}$ Muhammad Ibn Isa al-Tirmidhi, Sunan-al-Tirmidhi, Vol. 3, Egypt: Sharika Maktaba Wa Matbah Mustafa Albani, 1975, 328.
} 
examples of positive dealings with non-Muslims. ${ }^{68} \mathrm{He}$ maintained socioeconomic relations with the people of other religions. There is a report that the Prophet bonded his armourto a non-Muslim and used to accept invitations from non-Muslims.

Prophet Muhammad (pbuh)loved all human beings equitably. He disliked cursing including his enemies and always sought the mercy of Allah for all. When he went to Ta'if for preaching Islam, unbelievers persecuted him severely. Despite being persecuted, he prayed to Allah for their forgiveness. ${ }^{69}$

The Prophet (pbuh) set an example of generosity, compassion, and excellent neighbourhood. He nevertaughtMuslims to harm others. Abu Hurairah narrated from the Prophet of Islam: "Anybody believing in Allah and the hereafter cannot cause sufferings to his neighbour". ${ }^{70}$ Many othertraditions stress the rights and dignity of neighbours irrespective of their religion and culture. For example, "He will not be a true believer, the Prophet repeated three times, from whose hand his neighbour is not safe". ${ }^{71}$

The Prophet (pbuh) also said: "Gibrael (Gabriel) used to advise me to treat my neighbour as though they are my heirs". ${ }^{72}$ A Muslim cannot be a true Muslim unless he considers his neighbour as himself, and he cannot cause suffering to his neighbour in any circumstance. Islam includes everybody whether believers, unbelievers, atheists, idolaters, etc., they will be included as neighbours in any Muslim society. ${ }^{73}$ To be a true

${ }^{68}$ Muhammad Zia ul-Haq, M. Z., "Muslim's Participation in Interfaith Dialogue: Challenges and Opportunity”, Journal of Ecumenical Studies, Volume 49, (2014), 613-646.

${ }^{69}$ Ahmed Ahmed Galush, Sirat al-Nababiyyah wa al-Dawah Fi al-Ahd al-Makki, Beirut: Muassatu al Risalah, 2003, 500.

${ }^{70}$ Muhammad Ismael al-Bukhari, al-Bukhari in Mawsuah al-Hadith al Sharif al Kutub alSittah, Riyad: Dar al Salam, 2008, 6018.

${ }^{71}$ Muhammad Ismael al-Bukhari, al-Bukhari..., 6016.

${ }^{72}$ Muhammad Ismael al-Bukhari, al-Bukhari..., 6014.

${ }^{73}$ Ibn Hamid, The Rights of Neighbours in Islam, 2013. Available online: www.Islamland. 
Muslim, a person must behave well towardshis neighbours irrespective of religion. Jabir Ibn Abdullah narrated that "once we along with the Prophet were passing by a funeral procession. When the Prophet (pbuh) saw this, he stood up, and we also stood up following him. Then we informed the Prophet (pbuh) that it was the dead body of a Jew. The Prophet (pbuh) replied that when you saw a funeral procession you would stand up" ${ }^{74}$ According to another narration, "Once a funeral procession was crossing the Prophet (pbuh) and observing this he stood up. Then he was informed that the person was a Jew. The Prophet (pbuh) responded, was he not a human being?". ${ }^{75}$ These two important traditions clarify the genuine attitude of the Prophet (pbuh) toward the people of other religions. His respect for a non-Muslim funeral procession shows how Muslims should deal with non-Muslims.

An important event that reflects the tremendous respect and tolerance of the Prophet (pbuh) to non-Muslims occurred in the aftermath of the battle of Khaibar when the Prophet (pbuh) ordered the return of all the scriptures of the Jews. The Prophet (pbuh) warned against those who treat a non-Muslim unfairly. According to an authentic tradition, Muhammad (pbuh) said: "Anybody does injustice to a Dhimmi (non-Muslim living in an Islamic state)or belittle him or impose anything upon him beyond his ability or take something from him without his permission I will be the witness against him in the Day of Judgement" ${ }^{76}$

Imam Al-Qarafi as quoted by Abu Munshar mentioned that fair treatment (birr) to non-Muslims is as follows:

"Showing kindness to their weak and helping their poor and destitute, and

\footnotetext{
Com. Accessed on 06 December, 2017.

${ }^{74}$ Muhammad Ismael al-Bukhari, al-Bukhari..., 102.

${ }^{75}$ Muhammad Ismael al-Bukhari, al-Bukhari..., 102.

${ }^{76}$ Abu Dawd Sulaiman, Sunan-e Abi-Dawd, Vol. 3, Beirut: AlMaktaba al Asriyyah, n.d.,
} 170. 
feeding their hungry, clothing their necked, and uttering kind words to them from the position of grace and mercy and not from the position of fear and disgrace and removing their hardship as their neighbours if you (Muslims) have power to remove it, praying for their guidance so that they can become happy and fortunate people, giving them good advice in all their affairs the affairs of this world and the hereafter and looking after their interest in their absence. If anyone hurts them and deprives them of their property or family, possessions or their rights, you should help them by removing their persecution and make sure to restore all their rights back to them". ${ }^{77}$

The Prophet (pbuh) praised good people and their actions regardless of their religion. In the fifth year of the Prophethood, Muhammad (pbuh) instructed his companions to migrate to Abyssinia (Ethiopia) and told them that there was a king Najashi who was a good ruler. Praising his rule, the Prophet (pbuh) said that he was not unjust to his subjects. ${ }^{78}$ The Prophet (pbuh) also took shelter from non-Muslims. For instance, after the persecution by the people of Ta'if, the Prophet (pbuh) returned to Makkah under the protection of Al-Mut'im, a non-Muslim. ${ }^{79}$ This indicates that the Prophet (pbuh) not only showed equal treatment to non-Muslims but also trusted them.

During the Prophetic mission of Muhammad (pbuh) (610 CE- 622 $\mathrm{CE})$, the Makkan polytheists opposed the Prophet and his followers and caused tremendous suffering which compelled them to migrate to Madinah. After the victory of Makkah in $622 \mathrm{CE}$, when the Prophet (pbuh) returned home, he could have taken revenge for their treachery and plotting. Instead, he said to them, "no blame would be imposed upon you and Allah would forgive you" ${ }^{80} \mathrm{He}$ also said to them, "go back to your home, you are completely free". ${ }^{81}$ John L. Esposito mentions

${ }^{77}$ Maher Y. Abu-Munshar, "Islamic Source..., 19.

${ }^{78}$ Abu al-Fadl Ismael Ibn Kathir, al-Bidāyah Wa al-Nihāyah, vol. 3, Beirut: Dār al-ḥyā' alTurāth al-Arabỉ, 1998, 85.

${ }^{79}$ Saifur Rahman al-Mubarakpuri, al-Rahị al-Makhtum, Damascus: Dār al-Asama, 2006, 77.

${ }^{80}$ Abu Abdullah Muhammad al-Qurtubi, al-Jāmi' al-Ahkām al-Qur'ān, vol. 9, Cairo: Dār al-Kutub al-Mișriyyah, 1964, 258.

${ }^{81}$ Muhammad Rashid, Tafsir al Manār, Vol. 3, Cairo: Haiyah al Mișriyyah al-'Āmmah li al-Kitāb, 1990, 230. 
that Meccans thought that Muhammad would take revenge fortheir persecution, but he granted them amnesty. ${ }^{82}$

The polytheists severely hurt the Prophet (pbuh) in the battle of Uhud, which caused his teeth to split open and bleed. Even at that moment, the Prophet prayed to Allah for their forgiveness by saying that, " $O$ ' Allah! Forgive them for they know not what they do". ${ }^{83}$

A woman called Ummu Jamil used to spread thorns on the road the Prophet would walk.The Prophet (pbuh) used to remove the thorns from the road while passing and never scolded her. ${ }^{84}$ It is supported by the Quran that the Prophet will be tested by wealth, persecution, hurtful words and abuse and Allah counselled him to remain patient. ${ }^{85}$

Prophet Muhammad (pbuh) favoured self-restraint and gentleness in dealing with people of different religions. Urowat Ibn Jubair narratedthat "once the Prophet (pbuh) was sitting along with his wife, A'ishah, and a fewcompanions. A group of Jews was passing them and said: 'Assaamalaikum' (May death be upon you). The Prophet did not respond to the Jews and kept silent. But, Aishah, the Prophet's wife, responded angrily by saying 'As-saamalaikumwa'lla'nah' (may death and curses be upon you). On hearing this response from Aisha, the Prophet persuaded Aisha by saying, 'Allah loves gentleness'. ${ }^{86}$

Abu Hurairahnarrated that one day Abu Bakar (one of the close friends of the Prophet and the first caliph of Islam) was subjected to verbal abuse by a Jewish man and Muhammad (pbuh) was sitting close to him. Abu Bakar bore patiently and remained silent despite this vehement

\footnotetext{
82 John L. Esposito, "Mohammad and the Quran", in Islam: The straight Path, Oxford University Press, 1988, 12.

${ }^{83}$ Muslim Ibn Hajjaj, Sahih al Muslim, Vol, 3, Beirut: Dāru al-Iḥyā' al-Turath al-Arabí, n.d.,1415.

${ }^{84}$ Abu Abdullah Muhammad al-Qurtubi, Al-Jämi'..., 240.

${ }^{85}$ Al-Qur'an, 3: 186.

${ }^{86}$ Muhammad Ibn Ismael al-Bukhari, Sahih al-Bukhari..., vol. 8, 12.
} 
abuse. Observing the silence of Abu Bakar, the Prophet smiled. After remaining silent, when Abu Bakar responded to the Jew, the Prophet stood up and walked away. Abu Bakar followed the Prophet (pbuh) and asked, O Messenger of Allah, while this man was mistreating me, you were sitting close to me, and when Iresponded to him, you went away. Muhammad (pbuh) answered by saying that so longas you did not respond to the man, the angels of Allah were responding on your behalf, and whenever you started to respond, Allah's angels went away and Satan arrived. So, I cannot remain there. ${ }^{87}$ Another Hadith is narrated by Abu Said al-Khudri that "Once a Jew and a Muslim were quarrelling over the issue of superiority regarding their Prophets concerned. When this was informed to Muhammad (pbuh), he admonished the Muslim and said: do not magnify one Prophet over another". 88

Patience and gentleness are effective forces in social interaction for building a peaceful society. The examples in the life of Muhammad (pbuh) are enlightening for any human being whatever religion he or she follows. The above traditions show how Muslims should deal with non-Muslims while being abused by them. Muslims are advised to remain patient and are not allowed to abuse non-Muslims in return.It also teaches that Muslims should not quarrel with non-Muslims over the superiority of any Prophet of Allah.

After the Prophet (pbuh), the rightly guided Caliphs followed his teachings. Abu Yusuf narrates that during the reign of the four righteous Caliphs, there were many agreements between Muslims and non-Muslims and the Caliphsrespected those agreements. Temples, churches, and synagogues were protected, and the non-Muslims practised their religion

\footnotetext{
${ }^{87}$ Ahmad Ibn Hambal, Musnad al Imam Ahmad, Vol. 15, Beirut: Muassase Risalat, 2001, 390.

${ }^{88}$ Muhammad Ibn Ismael al-Bukhari, al-Bukhari ..., Vol. 3, 121.
} 
freely. ${ }^{89}$ When Jerusalem was conquered by the Romans in $114 \mathrm{CE}$, all the Jews were expelled from the city. ${ }^{90}$ On the other hand, when Jerusalem came under Islamic rule in $638 \mathrm{CE}$, Umar signed a treaty with its citizens granting the security of their life and property. It also granted the Jews and Christians to practice their religionfreely. ${ }^{91}$ History shows that it was the Muslims under whom there were no restraints for the people of any race and religion in Bayt al-Maqdis. ${ }^{92}$ Bayt al-Maqdis became a safe haven for the people of different religions and cultural backgrounds only when it came under Muslim rule. ${ }^{93}$ There is evidence that non-Muslims were treatedwelland their cultural and religious identities were respected and protected under the rule ofthe Al-Rashidun Caliphate, the Umayyads, Abbasids, Seljuks and Ottomans. ${ }^{94}$ They were inspired to join political posts in the Muslim community. Some of them also held high posts in many public offices under Muslim rule.

\section{Conclusion}

The study reveals that every individual is free. There is no ancestral limitation or inherent obstacle for subjugating an individual..$^{95}$ Freedom is a shared value between individuals ${ }^{96}$ and justice is the pre-condition for

\footnotetext{
${ }^{89}$ Abu Yusuf Yaqub, Kharaj, Cairo: Maktaba al-Azharia, n. d., 160.

${ }^{90}$ Ahmad, F. Yousif, Religious Freedom..., 41.

${ }^{91}$ Maher Y. Abu-Munshar, "Islamic Sources..., 88.

${ }_{92}$ Mohd Roslan Mohd Nor, Islamic jerusalem under Muslim Rule: A study of the Implementation of Inclusive Vision on the Region, Journal of Al-Tamaddun, Volume 3, Number 1 (2008), 186-208.

${ }^{93}$ Mohd Roslan Mohd Nor, " Protecting Non-Muslims: Its Implementation during Early Muslim Rule of Islamicjerusalem”, Al-Bayan: Journal of Qur'an and Hadith Studies, Volume 9, Number 1 (2011), 209-249.

${ }^{94}$ Ahmet Kurucan and Mustafa Kasim Erol, "Dialogue in Islam.

${ }^{95}$ Richard Dien Winfield, "Islam and Modernity", in Modernity, Religion, and the War on Terror, Burlington: Ashgate Publishing Company, 2007, 96.

${ }^{96}$ Abdul Hai Madani, "Freedom and Its Concept in Islam", 2nd International Conference on Humanities, Historical and Social Sciences IPEDR Singapore, vol.17, (2011), 16-20.
} 
exercising freedom. Freedom cannot be exercisedby violating justice. The Quranic injunction regardingfreedom of religioncame long before the Prophet's migration to Madinah.The Quran teaches that individuals are free to accept or reject Islam, and Muslims can never force theacceptance oflslam.In an Islamic state, non-Muslims are free to practice their religion, celebrate their religious festivals, establish their religious institutions, propagate their religious activities and maintain their religious law. The Prophet Muhammad (pbuh) never imposed Islamic law on non-Muslims in Madinah. He used to visit the religious institutions of the Jews in Madinah and ensure the freedom to learntheir religion. The inclusiveness of Islamic law manifests through the recognition of other people's dignity and rights. ${ }^{97}$

The basic principle of Islam is Tawhidand the multiplicity of His creation. Tawhid focuses on the essential unity of humankind regardless of their religion and culture.A number of Quranic verses urge Muslims to foster justice, kindness, and harmonious relationships with the people of other religion and culture. ${ }^{98}$ There are manyexamples of generous dealings and fair treatment of the Prophet (pbuh) with the people of different religions. The Prophet (pbuh) established a community comprising Muslims, Jewish, polytheistic and many ethnic groups of Madinah.Heformeda charter known as the 'Charter of Madinah' based on shared goals which aimed to protect the lives and properties of its citizens in Madinah, fight against injustice irrespective of religious or cultural affiliation and ensure religious freedom. The Prophet made many agreements with people of differentreligious and ethnic backgroundswith a view to establish peace and harmony. The agreement with the Christians of Najran is a unique

\footnotetext{
${ }^{97}$ Osman Bakar, "Islam and Challenge of Diversity and Pluralism: Must Islam Reform Itself?", in Islam and Civilizational Renewal vol.1, Kuala Lumpur: International Institute of Advanced Islamic Studies, 2009, 68-69.

${ }^{98}$ Al-Qur'an, 49: 13; 16: 125; 3: 64
} 
example of the Prophet's treatment of non-Muslims.In short, if the teachings of the Quran and the Prophetic Sunnahregarding religious freedom and interreligious relationship are maintained, conflict, hatred, and mistrust will be reducedand peace, harmony and coexistence will be established in multi-religious and multicultural societies.

Acknowledgement: The authors would like to thank the University of Malaya for providing financial assistance to carry out this research under the research grant UMRG RP035D-17HNE.

\section{Bibliography}

Hisham, Abd al-Malik Ibn. Sirah al-Nababiyah, Vol. 1. Egypt: Sharika Maktaba, 1955.

Siddiqui, Abdul Hamid, The Life of Muhammad. Kuala Lumpur: Islamic Book Trust, 1999.

Madani, Abdul Hai, "Freedom and Its Concept in Islam", 2nd International Conference on Humanities, Historical and Social Sciences IPEDR vol.17, Singapore: IACSIT Press, 2011.

Al Masud, Abdullah, and Mohammad Elius, "The Quranic View of Interreligious Dialogue and Harmony", International Journal of Recent Research in Social Sciences and Humanities, Volume 3 (2016): 18-21.

Albani, Abu Abdur Rahman Muhammad Nasir Uddin. Silsilatu alAhadith al-Sahihah, Vol. 6. Riyad: Maktabat al Maaref, 1996.

al-Qurtubi, Abu Abdullah Muhammad, Al-Jami al-Ahkam al-Qur'an, Cairo: Dar al Qutb al Mișriyyah, 1964.

Abu Dawd Sulaiman. Sunan Abi Dawd, Vol. 3. Beirut: Al-Maktaba al Asriyyah, n.d.

Kathir, Abu al-Fadl Ismael Ibn. Al-Bidāyah Wa al-Nihāyah, Vol. 3. Beirut: Dar al-Ihya al-Turath al-Arabi, 1998.

Yaqub, Abu Yusuf, Kharaj. Cairo: Maktaba al-Azharia, n. d..

Hambal, Ahmad Ibn. Musnad al Imam Ahmad, Vol. 15. Beirut: Muassase Risalat, 2001.

Yousif, Ahmad F., Religious Freedom, Minorities and Islam: An Inquiry into the Malaysian Experience. Selangor Darul Ehsan: Thinkers Library, 1998. 
Galush, Ahmed A. Sirah al-Nababiyyah wa al-Da'wah fi al-Ahd al-Makki. Beirut: Muassatu al Risalah, 2003.

Zewail, Ahmed, "Dialogue of Civilizations: Making History through a New World Vision”, in Jean Staune(ed.), SCIENCE Ethe Search for Meaning: Perspective from International Scientists, London: Templeton Foundation Press, 2006.

Kurucan, Ahmet, and Mustafa Kasim Erol. Dialogue in Islam: Quran Sunnah - History. London: Dialogue Society, 2012.

Yitik, Ali Ihsan, "Islam and Pluralism: Does Qur'an Approve Pluralism”, Journal of Religious Culture, Volume 68, (2004): 1-5. Available online: http://publikationen.ub.uni-frankfurt.de/opus4/frontdoor/ index/index/docId/468. Accessed 20 June 2018.

Bhat, Ali Muhammad, "Freedom of expression from Islamic perspective", Journal of Media and Communication Studies. Volume 6, Number 5 (2014): 69-77.

Mondal, Anshuman A, "Articles of Faith: Freedom of Expression and Religious Freedom in Contemporary Multiculture", Islam and Christian-Muslim Relations, Volume 27, Number 1(2016): 3-24. DOI: 10.1080/09596410.2015.1114240

Bayram, Fatma, "What is Religion?". 2010. Accessed December 5, 2017. http://www.lastprophet.info/what-is-religion.

Haque, Faatin, "Countering Religious Militancy through Interfaith Cooperation: An Islamic Perspective”, World Universities Congress, Canakkale Onsekiz University, Turkey, 2010.

Sarwar, Hafiz Ghulam, "Darkness and Dawn" in Life of Muhammad. London: The Writers House, 2010.

Wani, Hilal, Raihanah Abdullah, and Lee Wei Chang, "An Islamic Perspective in Managing Religious Diversity", Religions Volume 6, Number 2(2015): 642-656. DOI: 10.3390/rel6020642.

Hamid, Ibn. The Rights of Neighbours in Islam. 2013. Accessed on 06 December, 2017, Available at: www. Islamland.com.

Esposito, John L., "Mohammad and the Quran: Messenger and Message", in Islam: The Straight Path, London: Oxford University Press, 1988. 
IJIMS: Indonesian Journal of Islam and Muslim Societies, Volume 8, Number 2, December 2018: 309-334

Karim, Khairulnizam Mat, Suzy Aziziyana Saili, "Inter-faith dialogue: The Qur'anic and Prophetic Perspective", Journal of Usuluddin,Volume 29 (2009): 65-94.

Hambali, Khadijah Mohd Khambali, "Dialogue of Life: An Experience in Leeds Community”, Journal of Usuluddin, Volume 41 (2015): 147167.

Munshar, Maher Y. Abu, "Islamic Sources and the Treatment of nonMuslims", in Islamic Jerusalem and Its Christians: A History of Tolerance and Tensions, New York: Tauris Academic Studies, 2007.

Ali, Mohammadi, "The Culture of Politics of Human Rights in the Context of Islam", in Islam Encountering Globalization, USA: Routledge Curzon, 2002.

Nor, Mohd Roslan Mohd, "Religious Tolerance in Malaysia: An Overview", Middle- East Journal of Scientific Research,Volume 9, Number 1(2011): 23-27.

Nor, Mohd Roslan Mohd, "Protecting Non-Muslims: Its Implementation during Early Muslim Rule of Islamicjerusalem”, Al-Bayan: Journal of Qur'an and Hadith Studies, Volume 9, Number 1(2011): 209-249.

Nor, Mohd Roslan Mohd, "Islamicjerusalem under Muslim Rule: A study of the Implementation of Inclusive Vision on the Region", Journal of Al-Tamaddun, Volume 3, Number 1 (2008): 186-208.

Kadivar, Mohsen, "Apostasy, Blasphemy, \& Religious Freedom in Islam: A Critique Based on Demonstrative Jurisprudence", in Islam and Human Rights Series, No. 2, 2014. Accessed on January 2, 2018, Available at: http://kadivar.com.

Kamali, Muhammad Hashim, "Diversity and Pluralism: A Qur'anic Perspective", Islam and Civilizational Renewal. Volume 1, Number 1 (2009): 27-54.

Tabari, Muhammad Ibn Jarir al-. Jämi' al-Baiyān Fĩ Tawil al- Qữan, Vol.10. Beirut: Muassalah al-Risalah, 2000.

Hasan, Muhammad Haniff, "Interpreting Islam and Plural Society", Islam and Civilizational Renewal, Volume 1, Number 1 (2009): 99. 121.

Tirmidhi, Muhammad Ibn Isa al-, Sunan-al -Tirmidhi, vol. 3. Egypt: Sharika Maktaba Wa Matbah Mustafa Albani Al-Hobla, 1975. 
Bukhari, Muhammad Ismael al-, Al-Bukhari Riyad: Dar al-Salam, 2008. al-Bukhari, Muhammad Ibn Ismael, Sahịh al-Bukhārī, Vol. 8. Beirut: Dār al- Turuk al- Nazal, 2001.

Redha, Muhammad Rashid, Tafsir al Manar, Vol. 3. Cairo: Haiyah alMisriyyah al-Ammah li al-Kitab, 1990.

Haq, Muhammad Zia ul-, "Muslim's Participation in Interfaith Dialogue: Challenges and Opportunity", Journal of Ecumenical Studies, Volume 49 (2014): 613-646.

Hajjaj, Muslim Ibn, Sahịh al Muslim, Vol, 3. Beirut: Dār Iḥyā' al-Turāth al-Arabi, n.d..

Bakar, Osman, "Islam and Challenge of Diversity and Pluralism: Must Islam Reform Itself?", Islam and Civilizational Renewal, Volume 1, Number 1 (2009): 55-73.

Zümrüt, Osman, "Some Reflections on Islamic View of Other Divine Religions within the Context of Inter-religious Dialogue", Journal of Religious Culture, Volume 91 (2007): 1-7. Available online:http:// publikationen.ub.uni-frankfurt.de/opus4/frontdoor/index/index/ docId/493. Accessed on 20 June 2018.

Winfield, Richard Dien, "Islam and Modernity", in Modernity, Religion, and the War on Terror. Burlington: Ashgate Publishing Company, 2007.

Ismail, Siti Zubaidah, and Muhamad Zahiri Awang Mat, "Faith and Freedom: The Qur'anic Notion of Freedom of Religion vs. the Act of Changing Religion and Thoughts on the Implications for Malaysia,"Religions, Volume 7, Number 7 (2016): 1-18. DOI:10.3390/ rel7070088

Husain, Syed Anwar, "Islamic perspective of interfaith harmony and dialogue", The $2^{\text {nd }}$ International Conference on Interreligious and Intercultural Dialogue, Dhaka: University of Dhaka, Nov. 27-29, 2010.

Mandour, Taysir M., "Islam and Religious Freedom: Role of Interfaith Dialogue in Promoting Global Peace”, BYUL. Rev.,Volume 3, (2010): 885-893. Available at: https://digitalcommons.law.byu.edu/ lawreview/vol2010/iss3/10. 
IJIMS: Indonesian Journal of Islam and Muslim Societies, Volume 8, Number 2, December 2018: 309-334

V. F. Vineeth,C.M. I., "Interreligious Dialogue: Past and Present a Critical Appraisal”, Journal of Dharma: Dharmaram Journal of Religions and Philosophies, Volume 19, Number 1 (1994): 36-58. 